\title{
Comparison of the Ability to Develop Competencies Among the Face-to-Face, E-learning, and B-learning Modalities: From Behaviorism or Constructivism
}

\author{
Salvador Ceja Oseguera, María Josefina Rivero-Villar, \\ Laura Mayela Ramírez Murillo, Tito Livio de la Torre Hidalgo \\ Universidad Popular Autónoma del Estado de Puebla, Puebla, México
}

\begin{abstract}
In a highly complex, competitive, and innovative globalized world, the topic of competencies has emerged as means to link universities with the real needs of the firms. But this topic far from being clear is confusing and ambiguous in the specialized literature. Competencies have been classified in education according to two approaches_-behaviorism and constructivism and a polemic arises when trying to determine which of them prevails in higher education. The Mexican Ministry of Education (SEP) asserts that the constructivist approach prevails in Mexico, while the one behaviorist has considerably diminished in the face-to-face, e-learning, and b-learning modalities. A non-experimental, quantitative, descriptive, and simple cross-sectional research was designed with the aim to analyze the effectiveness of the different educational modalities to develop competencies at the undergraduate schools of the business area of UPAEP. The results show that a behaviorist approach prevails even if the discourse is constructivist.
\end{abstract}

Keywords: education, instruction modalities, online, b-learning, behaviorism, constructivism

\section{Introduction}

The topic of competencies was proposed in higher education to face the challenge of strengthening the teaching-learning process; but up to the present, it has been used in the face-to-face modality and there is little evidence of what e-learning and b-learning allow to develop. In this sense, it is obvious that the research problem of this investigation has not been answered by the studies on competencies made to this date.

The term competencies, was applied to labor when it was first introduced, and its purpose was filling the gaps in the instruction for a job. But this situation has changed until becoming a new option in the education realms. According to the Organization for the Cooperation and Economic Development (OCED) DeSeCo (2005) Project, competencies are abilities to successfully satisfy the complex demands of a given context. Higher education has been enriched with new education modalities that stem from the development of

Salvador Ceja Oseguera, Ph.D., Centro Interdisciplinario de Posgrados, Universidad Popular Autónoma del Estado de Puebla.

María Josefina Rivero-Villar, Ph.D., Centro Interdisciplinario de Posgrados, Universidad Popular Autónoma del Estado de Puebla.

Laura Mayela Ramírez Murillo, Ph.D., Escuela de Negocios, Universidad Popular Autónoma del Estado de Puebla.

Tito Livio de la Torre Hidalgo, Ph.D., Escuela de Negocios, Universidad Popular Autónoma del Estado de Puebla.

Correspondence concerning this article should be addressed to Salvador Ceja Oseguera, 17 Sur 901, Puebla, México, C.P. 72410.

E-mail: salvador.ceja@upaep.mx. 
information and communication technologies (ICTs) and more recently with learning and knowledge technologies (LKTs) that have changed the educative process into a techno-educational one. Among the new modalities online courses (e-learning) and more recently blended courses (b-learning) outstand. The proliferation of both kinds of courses has allowed the incursion to new interactive forms of learning, where e-learning is centered in the intensive use of technical media (on-line courses, e-mail, audiovisuals, and so on) and the student is the center; although b-learning makes use of technical media (videoconferences), both student and teacher are the axis of the educative process and it is closer to the traditional concept of education (García, 2001).

There is such a wide arrange of research about competencies, which may be divided into topics. There are studies in the business area that mention the advantages of instruction based on competencies that consider them as a series of individual personality traits as well as the skills and abilities required for their professional job (Alles, 2002; Levy-Leboyer, 2000; González \& Wagennar, 2006; Silva, 2008; Argudín, 2009). Other studies link competencies to job, dividing them according to three approaches in what to the amount of responsibility and skills for the job refers: the functionalist, the behaviorist, and the constructivist approaches (Mertens, 1996; Barrón, 2000; De Ibarrola, 2004; Frade, 2007). In education, the research has been divided into the one that analyzed the functionalist, behaviorist, and constructivist characteristics of competencies (Ibarra, 1994; Somovia, 1999; Westera, 2001) and that devoted to determine the prevailing approach in higher education. Most research concludes that the behaviorist approach prevails in Mexico and the negative effects of this fact (Barnet, 2001; Pérez, 2007, Moreno, 2009). Even though some authors consider that the change in education towards a constructivist approach is present, really it is not (Mansfield, 2004; Perrenoud, 2008).

In the case of educative modalities and their link to information technologies, the most comprehensive studies analyze the changes that have taken place in the teaching-learning process most of all in face-to-face education (Cabero, 1994; Andrade \& Campo-Redondo, 2008). There are also researches on the pedagogic achievement of online courses (Argudín, 2009) and more recently studies mentioning the benefits of mixed or blended education (Cánchica, Chirinos, Cansen, Medina, \& Reyes, 2008; Turpo, 2009). But there is a lack of information related to the development of competencies in the different educative modalities.

This research aims at comparing the behaviorist and constructivist approaches to develop competencies in the three modalities: face-to-face, e-learning, and b-courses at UPAEP's Business School, to identify the prevailing approach in each of them. This kind of research contributes to reinforcing the idea that learning based on competencies can make a contribution to higher education when the behaviorist elements are separated or palliated and constructivist practices are reinforced in education.

The research is divided into five sections: introduction; literature review, hypothesis, and model of study, methodology; discussion and analysis of results and finally conclusions.

\section{Literature Review}

Competencies, as a concept, has a wide array of orientations; in business area competencies are considered as a series of personality traits, as well as skills and abilities required for the accomplishment of certain activities (Alles, 2002; Levy-Leboyer, 2000; González \& Wagennar, 2003; Silva, 2008; Argudín, 2009). One of the representative authors of this area is Levy-Leboyer (2000) who considered that competencies may be divided into four aspects: intellectual competencies (perspective, strategic, analysis and common sense, planning and organization); interpersonal competencies (lead collaborators, persuasion, decision, interpersonal 
sensibility, oral communication); adaptability competencies: adaptation to the environment; competencies for results (energy, initiative, need for success, sensitivity for business). Another common subdivision in this area is the one proposed by Alles (2002) who divided competencies into basic and generic: basic competencies (skills to read, write, oral communication, and calculus); and generic competencies (skills for the job, learning ability, analysis ability, synthesis, planning, and team work).

Mertens (1996) outstood in the area that linked competencies with work. He starts a division of competencies over the basis of three approaches according to the kind of learning of individuals, the degree of responsibility and each one's abilities for work: the functionalist, behaviorist, and constructivist approaches (Barrón, 2000). The funcionalist approach describes the workers' actions and results, emphasizing performance and the learning acquired by doing. The behaviorist approach is based on "the identification of the characteristics of the individual that cause the desired performance” (Mertens, 1996, p. 71). He has been criticized because his models were not adequate to flexible organizations. The constructivist approach emphasizes that competencies are built from the analysis and processing of the problem to be solved. In order to develop a competence, the subject, his objectives and possibilities must be considered, and proposes that less educated people must be included in competencies formation programs (De Ibarrola, 2004; Frade, 2007).

Among the researchers on education devoted to analyze the characteristics of competencies, there are some who consider their development is basically functionalist (Novick, Bartolomé, Miravalle, \& González, 1998; Somovia, 1999), these experts are in favor of technical education, where learning is by doing. It is a model used in the first educative projects of Technologic Universities, and their objective is to educate professionals with an egress profile according to the present demands of work of the world. In this kind of curriculum, competencies of abstract theoretical thinking, planning, synthesis, and analysis abilities are very important. On the other side, the researchers who consider competencies are basically behaviorist outstands the National Institute of Education Assessment (INEE) used by OCED, where behaviorist features may be detected, as the following definition attests: "competencies are the ability to put into practice abilities, knowledge and attitudes in an integral way to face and solve problems and situations” (INEE, 2005, p. 16). According to the behaviorist approach, the curriculum must develop knowledge, abilities, and attitudes which the professionals need to develop their professional life. Finally, specialists who consider competencies as basically constructivist, assure competencies are not formed from predetermined experiences but are developed and a result of the continuous improvement process, in this sense, competencies value subjectivity and motivational aspects and specifically, the importance of knowledge transformation and appropriation. It is to say that, in the constructivist approach the most important thing is not "what is learnt, but how it is learnt (Álvarez, Ayuste, Gros, Guerra, \& Romaña, 2005).

In what to the researches that analyze the deficiencies of a model by competencies with behaviorist basis outstands Moreno's (2009) work that affirms competencies are mistaken by abilities whose character is individual, and considered as observable behaviors and are not related with thinking attributes, so they promote uniformity and reduce learning to whether you know how to do it or you do not. "Learning by competencies cuts reality in digestible parts; evading the act of learning” (Barnet, 2001, p. 21). But there are some analysts like Perrenoud $(2004,2008)$ who considered competencies must not be discarded as education model, but must transfer knowledge and balance knowledge between knowledge generation and concrete skills and abilities, it is to say a balance between theory and practice. This trend supports that until now the constructivist approach has not been put into practice in the learning process; the discourse exists, so does the intention but the educative 
system limits its instrumentation. Constructivist conception of learning is not applied in today's school environment (Díaz Barriga, 2006).

The relationship between education and information technologies has largely been studied particularly the achievements present in the teaching learning process. New education modalities as online courses (e-learning) and blended or mixed courses (b-learning) changed the education focus and redefined space and time situations, modified contents and emphasized the use of virtual classrooms by the use of synchronic and asynchronous communication systems and provided flexibility to school activities (Cabero, 1994). In the case of online courses, the education model received benefits in different ways, it facilitates the significant assimilation of knowledge through different media to favor independent learning (SEP, 2008). It allows the interaction of students, teachers, and tutors, through strategies, activities and pedagogic and technologic resources, so that the student is involved in a responsible and independent manner in his/her own learning. In this model, the teacher promotes learning and coordinates the advancement of the subject, and the tutor offers psycho-pedagogic company. This modality has shown that the learning process is not an activity confined just to the classroom (Del Toro, 2006; Argudín, 2009). On the other side, the concept of blended learning (b-learning) is relatively new and is characterized by the use of face-to-face classes, videoconferences and even distance classes. This kind of courses combines face-to-face and distance alternatives. Turpo (2009) pointed out that b-learning or blended learning was an emergent instruction alternative product of the natural evolution of the online model in accordance with its failure. B-learning pretends to make teaching-learning process efficient by combining methods that bring better professional competencies out. Not much has been written on the development of competencies in the various educational modalities, particularly about online courses (e-learning) and blended courses (b-learning) and even less about comparisons among the three models and the application of the behaviorist or constructivist approaches to education have been made.

\section{Methodology}

A non-experimental, quantitative, descriptive, and simple cross-sectional research was designed to compare the prevailing approach in the face-to-face, online, and blended modalities at the undergraduate schools of the business area of UPAEP.

From the data of the students enrolled in the face-to-face modality from the business area provided by School Department, it was determined that 119 had coursed and approved more than $60 \%$ of the subjects included in their curriculum. The sample was calculated with a confidence interval of $95 \%$ and an error margin of $5 \%$ there were 91 students surveyed. From online modality, 51 students had approved the same percentage of subjects in their curriculum, so they were surveyed. In what to blended learning (b-learning) referred 26 students had the profile to be surveyed. The data gathering instrument had 44 items measured with a Likert 7 scale, distributed in the four dimensions of the model: communication, thinking, independent learning, and collaborative work, evaluated with 10,10,12, and 12 items respectively.

The model used for this research was Tuning Project for Latin America (2007) as shown in Figure 1. It proposed 27 generic competencies for higher education that were grouped by SEP (2008) into six categories, analyzing only four because they included the 27 proposed ones. The categories included are: that the students are able to adequately express and communicate, that they be able to think critically and reflectively, that they be able to independently learn and that they be able to work collaboratively. 


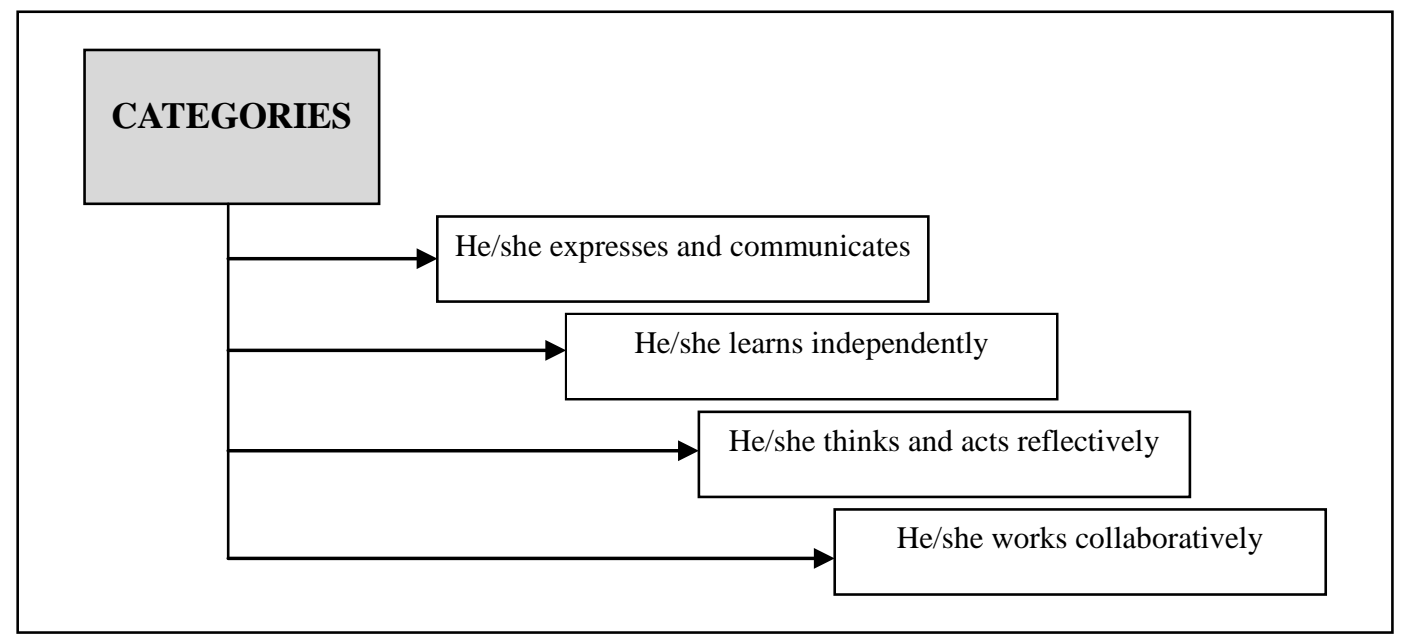

Figure 1. Categories that involve competencies.

\section{Research Design}

These four categories, as shown in Table 1, describe a series of generic competencies that are developed in face-to-face courses, online courses, and blended courses.

Table 1

Generic Competencies Developed by the Courses

\begin{tabular}{|l|l|}
\hline Categories & Competencies \\
\hline \multirow{2}{*}{ He/she expresses and communicates } & $\begin{array}{l}\text { He/she reads, interprets, and delivers pertinent messages in different contexts by the } \\
\text { use of digital media, codes and tools. }\end{array}$ \\
\hline \multirow{2}{*}{ He/she thinks critically and reflectively } & $\begin{array}{l}\text { He/she supports a personal point of view and makes decisions over relevant topics, } \\
\text { considering others points of view critically and reflectively. }\end{array}$ \\
\cline { 2 - 2 } He/she develops proposals and provides solutions by using established methods. \\
\hline He/she learns independently & He/she learns by his/her own interest and initiative. \\
\hline He/she works collaboratively & He/she participates and collaborates effectively in different groups. \\
\hline
\end{tabular}

The pilot test, as shown in Table 2, was made with 50 students from face-to-face modality in humanities area, 50 students from online modality and 25 from blended modality which assures that the instrument is confident because Cronbach's Alpha in all the cases is higher than 0.65 and the coefficients of all the dimensions have lower values than the total in the Cronbach's Alpha. It is valid because according to Vila, Küster, and Aldás (2002) all the correlations are significant and lower than Cronbach's Alpha of the corresponding dimension.

Table 2

Validation of the Data Gathering Instrument

\begin{tabular}{|c|c|c|c|c|c|c|c|c|c|c|c|c|}
\hline & \multicolumn{3}{|c|}{ Communication } & \multicolumn{3}{|c|}{ Critical thinking } & \multicolumn{3}{|c|}{ Independent learning } & \multicolumn{3}{|c|}{ Collaborative work } \\
\hline & b-learning & Face-to-face & Online & b-learning & Face-to-face & Online & b-learning & Face-to-face & Online & b-learning & Face-to-face & Online \\
\hline Communication & $0.668 \alpha$ & $0.669 \alpha$ & $0.700 \alpha$ & & & & & & & & & \\
\hline Critical thinking & $0.503\left(^{*}\right)$ & $0.564\left(^{*}\right)$ & $0.574\left(^{*}\right)$ & $0.723 \alpha$ & $0.724 \alpha$ & $0.724 \alpha$ & & & & & & \\
\hline $\begin{array}{l}\text { Independent } \\
\text { learning }\end{array}$ & $0.521\left(^{*}\right)$ & $0.582\left(^{*}\right)$ & $0.591\left(^{*}\right)$ & $0.557\left(^{*}\right)$ & $0.558\left(^{*}\right)$ & $0.558\left(^{*}\right)$ & $0.643 \alpha$ & $0.674 \alpha$ & $0.691 \alpha$ & & & \\
\hline $\begin{array}{l}\text { Collaborative } \\
\text { work }\end{array}$ & $0.599\left(^{*}\right)$ & $0.612\left(^{*}\right)$ & $0.605\left(^{*}\right)$ & $0.557\left(^{*}\right)$ & $0.645\left(^{*}\right)$ & $0.645\left(^{*}\right)$ & $0.583\left(^{*}\right)$ & $0.665\left(^{*}\right)$ & $0.597\left(^{*}\right)$ & $0.542 \alpha$ & $0.567 \alpha$ & $0.667 \alpha$ \\
\hline
\end{tabular}

Note. ${ }^{*}$ Correlation significant at 0.05 (bilateral); $\alpha$ : Cronbach’s alpha of the dimension. 


\section{Hypotheses}

H1: Competencies developed in face-to-face modality have a constructivist approach.

H2: Competencies developed in online modality have a constructivist approach.

H3: Competencies developed in blended modality have a constructivist approach.

\section{Results}

The averages of the categories, as shown in Table 3, are shown by dimension and by approach (impair numbers have a constructivist trend and pair numbers have behaviorist trend), and data from the items' minimum value, maximum value, average and variance with the highest and lowest values are highlighted.

Table 3

Category: Communication

\begin{tabular}{|c|c|c|c|c|c|c|c|c|c|c|c|c|c|c|c|}
\hline & \multicolumn{5}{|c|}{ b-learning } & \multicolumn{5}{|c|}{ Face-to-face } & \multicolumn{5}{|c|}{ Online } \\
\hline Communication & 䍐 & 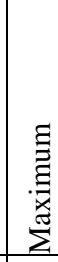 & 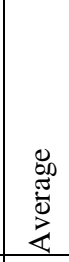 & 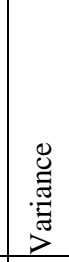 & 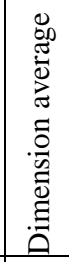 & 苯 & 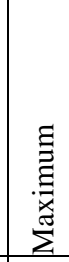 & 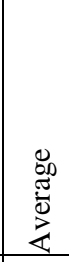 & 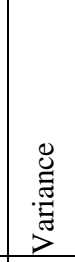 & 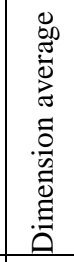 & 䍐 & 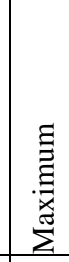 & 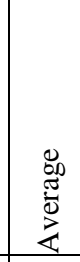 & 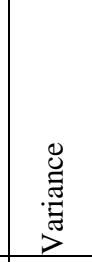 & 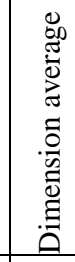 \\
\hline $\begin{array}{l}\text { 1. When you read texts, how much are you } \\
\text { asked to use analysis strategies and give your } \\
\text { opinion about them? }\end{array}$ & 3 & 7 & 4.73 & 1.32 & & 1 & 7 & 3.88 & 1.93 & & 1 & 7 & 4.82 & 1.788 & \\
\hline $\begin{array}{l}\text { 2. When you have had to read texts, how } \\
\text { often are you ask to make abstracts and } \\
\text { acquire knowledge? }\end{array}$ & 5 & 7 & 6.23 & 0.58 & & 1 & 7 & 4.93 & 2.02 & & 1 & 7 & 4.92 & 1.834 & \\
\hline $\begin{array}{l}\text { 3. When you make homework, how often } \\
\text { you have to write essays and make analysis } \\
\text { where you express your ideas? }\end{array}$ & 3 & 7 & 5.04 & 0.92 & & 1 & 7 & 4.51 & 2.72 & & 2 & 7 & 4.75 & 1.674 & \\
\hline $\begin{array}{l}\text { 4. When you make homework, how often do } \\
\text { you make abstracts and synthesis of what } \\
\text { you have read? }\end{array}$ & 5 & 7 & 6.00 & 0.40 & & 1 & 7 & 4.98 & 2.16 & & 2 & 7 & 4.73 & 1.723 & \\
\hline $\begin{array}{l}\begin{array}{l}\text { 5. When you have to express your } \\
\text { knowledge do you prefer to express it } \\
\text { through graphics, tables, diagrams, etc.? }\end{array} \\
\end{array}$ & 4 & 7 & 5.46 & 0.66 & 5.61 & 1 & 7 & 4.18 & 3.30 & 4.60 & 1 & 7 & 4.59 & 3.447 & 4.78 \\
\hline $\begin{array}{l}\text { 6. When you have to express your } \\
\text { knowledge do you prefer doing so through } \\
\text { abstracts and synthesis? }\end{array}$ & 5 & 7 & 6.42 & 0.33 & & 1 & 7 & 4.95 & 2.67 & & 1 & 7 & 4.61 & 3.083 & \\
\hline $\begin{array}{l}\text { 7. How often do you have asynchronous } \\
\text { communication (in different time) with your } \\
\text { teachers? }\end{array}$ & 4 & 7 & 5.19 & 0.72 & & 1 & 7 & 4.00 & 2.33 & & 1 & 7 & 3.71 & 2.972 & \\
\hline \begin{tabular}{|l|} 
8. How often do you have synchronic (real \\
time) communication with your teachers?
\end{tabular} & 4 & 7 & 6.04 & 0.68 & & 1 & 7 & 4.81 & 2.53 & & 2 & 7 & 5.59 & 1.567 & \\
\hline $\begin{array}{l}\text { 9. Do the ideas you write in your homework } \\
\text { reflect your way of thinking? }\end{array}$ & 4 & 6 & 4.58 & 0.41 & & 1 & 7 & 4.96 & 2.60 & & 2 & 7 & 5.80 & 1.401 & \\
\hline $\begin{array}{l}10 . \text { Do the ideas you write in your } \\
\text { homework are abstracts from the authors and } \\
\text { texts read? }\end{array}$ & 5 & 7 & 6.42 & 0.49 & & 1 & 7 & 4.82 & 1.92 & & 1 & 7 & 4.29 & 2.532 & \\
\hline
\end{tabular}

\begin{tabular}{|l|l|l|l|}
\hline Average & b-learning & Face-to-face & Online \\
\hline Behaviorist & 6.2 & 4.7 & 4.8 \\
\hline Constructivist & 5.0 & 5.2 & 4.7 \\
\hline
\end{tabular}


In the communication category, as shown in Table 4, it is evident that in average the most developed competencies are the behaviorist ones (6.2); while in face-to-face modality, the most developed are the constructivist ones (5.2); and in the online modality the most developed are the behaviorist ones (4.8).

Table 4

Category: Critical Thinking

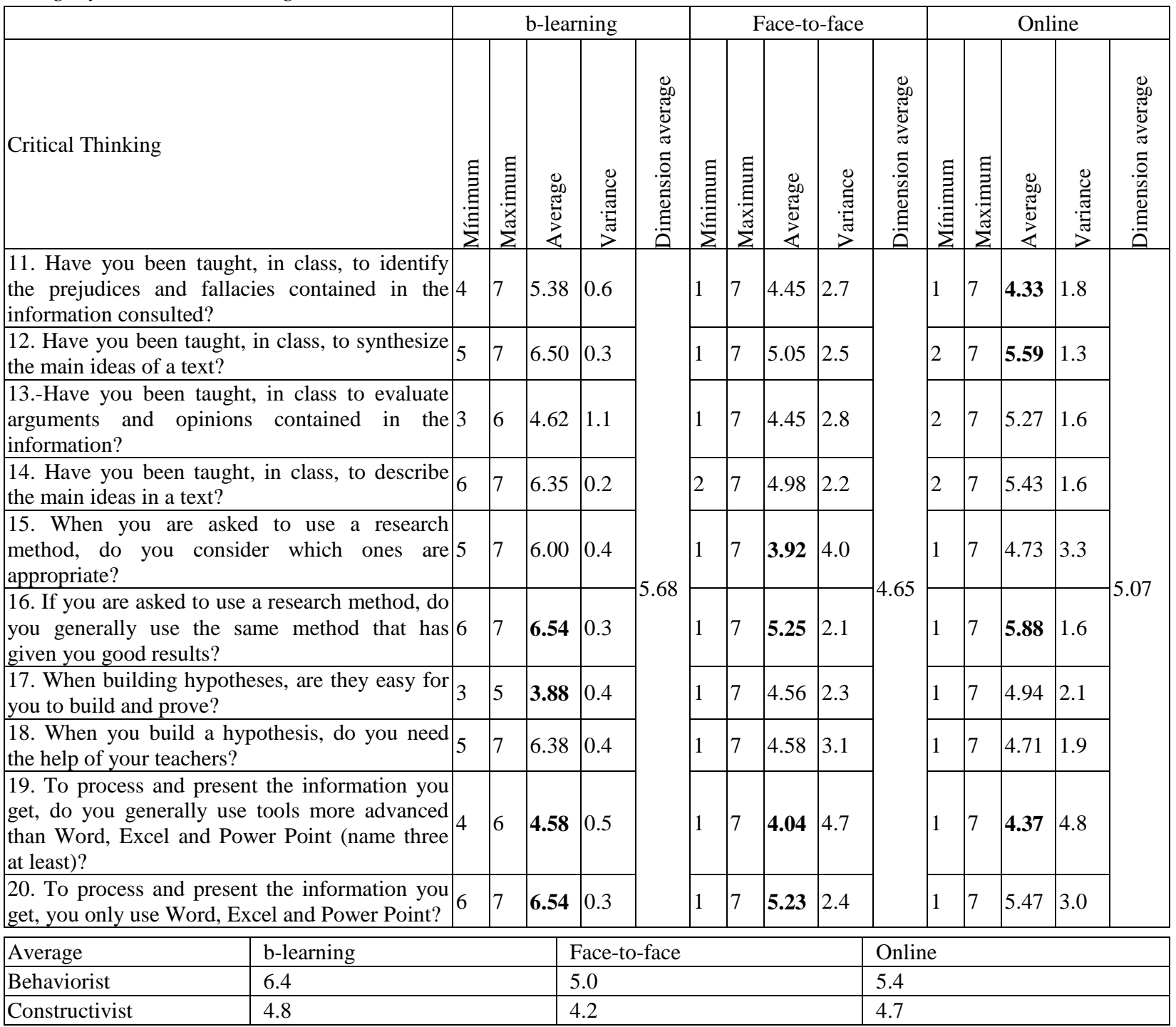

For the category critical thinking, the most developed modalities are the behaviorist ones for all three modalities.

For the category independent learning, the three modalities have constructivist competencies more developed.

In the case of independent learning, three modalities have a constructivist approach.

The hypotheses stated are contrasted with the obtained results.

H1: Competencies developed in face-to-face modality have a constructivist approach.

It was found that in the case of the categories independent learning, as shown in Table 5, and collaborative work a constructivist approach prevails, as shown in Table 6, while in the categories communication and 
critical thinking a behaviorist one prevails. In the final average of the four categories the behaviorist approach prevails. The hypothesis is rejected.

Table 5

Category: Independent Learning

\begin{tabular}{|c|c|c|c|c|c|c|c|c|c|c|c|c|c|c|c|}
\hline & \multicolumn{5}{|c|}{ b-learning } & \multicolumn{5}{|c|}{ Face-to-face } & \multicolumn{5}{|c|}{ Online } \\
\hline Independent Learning & 声 & 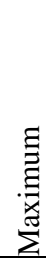 & 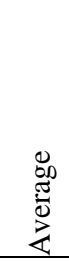 & 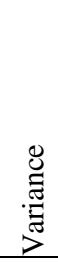 & 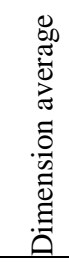 & 眔 & 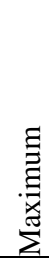 & $\begin{array}{l}\stackrel{0}{00} \\
\stackrel{0}{0} \\
\stackrel{4}{4}\end{array}$ & 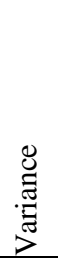 & 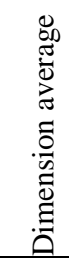 & 声 & 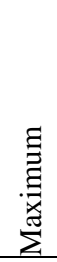 & 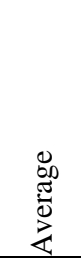 & 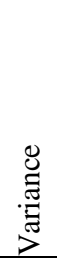 & 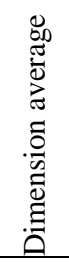 \\
\hline $\begin{array}{l}\text { 21. How much do you tend } \\
\text { to use information by your } \\
\text { own to increase your } \\
\text { knowledge? }\end{array}$ & 4 & 6 & 5.46 & 0.3 & & 1 & 7 & 4.66 & 2.3 & & 2 & 7 & 4.92 & 1.9 & \\
\hline $\begin{array}{l}\text { 22. How much do you use } \\
\text { the sources of information } \\
\text { suggested by your teachers? }\end{array}$ & 6 & 7 & 6.69 & 0.2 & & 2 & 7 & 5.30 & 1.8 & & 2 & 7 & 5.04 & 2.2 & \\
\hline $\begin{array}{l}\text { 23. Do you define and follow } \\
\text { up your own process of } \\
\text { knowledge construction? }\end{array}$ & 3 & 6 & 4.65 & 0.9 & & 1 & 7 & 4.54 & 2.0 & & 2 & 7 & 5.16 & 1.5 & \\
\hline $\begin{array}{l}\text { 24. Do you get better scores } \\
\text { when you learn by heart facts } \\
\text { and concepts? }\end{array}$ & 4 & 6 & 5.08 & 0.6 & & 1 & 7 & 5.02 & 2.5 & & 1 & 7 & 4.94 & 2.1 & \\
\hline $\begin{array}{l}\text { 25. Do you look for better } \\
\text { learning strategies to face the } \\
\text { challenges? }\end{array}$ & 5 & 7 & 6.46 & 0.5 & & 1 & 7 & 4.78 & 2.1 & & 1 & 7 & 5.08 & 1.7 & \\
\hline $\begin{array}{l}\text { 26. Do you usually use the } \\
\text { same strategies you have } \\
\text { already know to the } \\
\text { problems? }\end{array}$ & 3 & 5 & 4.08 & 0.5 & & 1 & 7 & 5.07 & 2.2 & & 2 & 7 & 5.16 & 1.4 & \\
\hline $\begin{array}{l}27 . \quad \text { Do you integrate } \\
\text { knowledge to develop your } \\
\text { work independently? }\end{array}$ & 3 & 7 & 6.50 & 0.7 & 5.41 & 1 & 7 & 5.00 & 2.1 & 4.90 & 2 & 7 & 5.33 & 1.2 & 5.13 \\
\hline $\begin{array}{l}\text { 28. What you learn mainly } \\
\text { depends in what the } \\
\text { professor teaches? }\end{array}$ & 4 & 6 & 4.65 & 0.4 & & 1 & 7 & 5.10 & 1.8 & & 2 & 7 & 5.27 & 1.3 & \\
\hline $\begin{array}{l}29 . \quad \text { Do you integrate } \\
\text { knowledge to solve real life } \\
\text { problems? }\end{array}$ & 5 & 7 & 6.27 & 0.4 & & 1 & 7 & 5.09 & 1.9 & & 2 & 7 & 5.41 & 1.6 & \\
\hline $\begin{array}{l}30 . \text { Do you integrate } \\
\text { knowledge, but don't know } \\
\text { how to solve real life } \\
\text { problems? }\end{array}$ & 3 & 5 & 4.19 & 0.5 & & 1 & 7 & 4.02 & 2.7 & & 1 & 7 & 4.06 & 3.3 & \\
\hline $\begin{array}{l}\text { 31. Have you considered that } \\
\text { what you learn is your own } \\
\text { responsibility? }\end{array}$ & 6 & 7 & 6.64 & 0.2 & & 1 & 9 & 5.53 & 2.6 & & 2 & 7 & 5.82 & 2.0 & \\
\hline $\begin{array}{l}\text { 32. Have you considered that } \\
\text { what you learn is result of } \\
\text { the action of you professors } \\
\text { and the university? }\end{array}$ & 3 & 6 & 4.2 & 0.5 & & 1 & 7 & 4.64 & 2.4 & & 1 & 7 & 5.35 & 2.3 & \\
\hline
\end{tabular}

\begin{tabular}{|l|l|l|l|}
\hline Average & b-learning & Face-to-face & Online \\
\hline Behaviorist & 4.9 & 4.8 & 4.9 \\
\hline Constructivist & 5.9 & 4.9 & 5.2 \\
\hline
\end{tabular}


Table 6

Category: Collaborative Work

\begin{tabular}{|c|c|c|c|c|c|c|c|c|c|c|c|c|c|c|c|}
\hline & \multicolumn{5}{|c|}{ b-learning } & \multicolumn{5}{|c|}{ Presencial } & \multicolumn{5}{|c|}{ Online } \\
\hline Collaborative Work & 罗 & 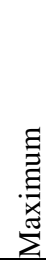 & 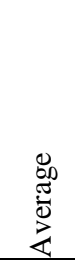 & 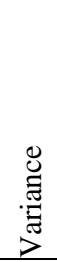 & 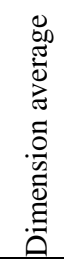 & 罡 & 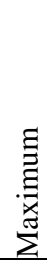 & 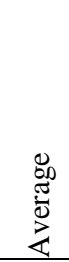 & 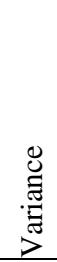 & 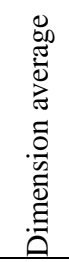 & 䍐 & 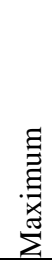 & 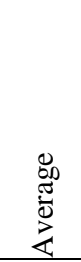 & 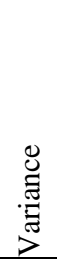 & 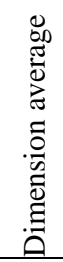 \\
\hline $\begin{array}{l}\text { 33. Have you considered that } \\
\text { all of us are different, but that } \\
\text { we are able to work in teams? }\end{array}$ & 5 & 7 & 6.42 & 0.6 & & 2 & 7 & 5.70 & 2.0 & & 1 & 7 & 5.86 & 2.3 & \\
\hline $\begin{array}{l}\text { 34. Have you considered that } \\
\text { all of us are different from } \\
\text { each other, and that is why } \\
\text { teamwork is difficult? }\end{array}$ & 4 & 6 & 4.69 & 0.5 & & 1 & 7 & 4.18 & 3.8 & & 1 & 7 & 5.35 & 2.3 & \\
\hline $\begin{array}{l}\text { 35. Do you consider others as } \\
\text { equals and respect their points } \\
\text { of view? }\end{array}$ & 5 & 7 & 6.15 & 0.5 & & 1 & 7 & 5.07 & 3.6 & & 2 & 7 & 5.22 & 1.9 & \\
\hline $\begin{array}{l}\text { 36. Do you consider others as } \\
\text { equals but it is difficult for } \\
\text { you to respect their points of } \\
\text { view? }\end{array}$ & 2 & 5 & 3.81 & 0.8 & & 1 & 7 & 3.65 & 3.8 & & 1 & 7 & 4.22 & 3.5 & \\
\hline $\begin{array}{l}\text { 37. Do you propose ways to } \\
\text { develop teamwork projects? }\end{array}$ & 5 & 7 & 6.27 & 0.4 & & 1 & 7 & 4.81 & 2.5 & & 2 & 7 & 5.18 & 1.9 & \\
\hline $\begin{array}{l}\text { 38. Have you preferred others } \\
\text { to propose teamwork projects? }\end{array}$ & 2 & 5 & 3.54 & 0.4 & $5-0$ & 1 & 7 & 4.38 & 3.0 & T7 & 1 & 7 & 4.41 & 3.0 & \\
\hline $\begin{array}{l}39 . \text { Do you reflectively } \\
\text { consider other people's points } \\
\text { of view? }\end{array}$ & 5 & 7 & 6.15 & 0.5 & 5.50 & 2 & 7 & 5.20 & 1.8 & 4.73 & 1 & 7 & 5.37 & 1.5 & 5.09 \\
\hline $\begin{array}{l}\text { 40. Do you distrust and } \\
\text { become defensive when others } \\
\text { develop teamwork projects? }\end{array}$ & 4 & 6 & 5.19 & 0.6 & & 1 & 7 & 4.02 & 2.8 & & 1 & 7 & 4.41 & 2.2 & \\
\hline $\begin{array}{l}\text { 41. How proactive are you } \\
\text { when you work in a team? }\end{array}$ & 5 & 7 & 6.50 & 0.3 & & 1 & 7 & 4.85 & 2.6 & & 2 & 7 & 5.86 & 1.1 & \\
\hline $\begin{array}{l}\text { 42. Are you retiring when you } \\
\text { need to show your abilities } \\
\text { when participating r of } \\
\text { teamwork? }\end{array}$ & 4 & 6 & 4.58 & 0.3 & & 1 & 7 & 4.67 & 3.5 & & 1 & 7 & 3.84 & 3.0 & \\
\hline $\begin{array}{l}\text { 43. Do you usually live virtues } \\
\text { such as justice, generosity, } \\
\text { charity and so on? }\end{array}$ & 5 & 7 & 6.38 & 0.6 & & 1 & 7 & 5.52 & 2.0 & & 3 & 7 & 5.88 & 1.2 & \\
\hline $\begin{array}{l}\text { 44. Are you taught in class } \\
\text { virtues such as justice, } \\
\text { generosity, charity, etc.? }\end{array}$ & 5 & 7 & 6.35 & 0.5 & & 1 & 7 & 4.71 & 3.3 & & 2 & 7 & 5.51 & 1.6 & \\
\hline
\end{tabular}

\begin{tabular}{|l|l|l|l|}
\hline Average & b-learning & Face-to-face & Online \\
\hline Behaviorist & 4.6 & 4.2 & 4.5 \\
\hline Constructivist & 6.3 & 5.19 & 4.7 \\
\hline
\end{tabular}

H2: Competencies developed in online modality have a constructivist approach.

It was found that only in independent work and collaborative work the constructivist approach prevails, but in the final average of the four categories the constructivist approach prevails. The hypothesis is accepted.

H3: Competencies developed in the blended learning modality have a constructivist approach.

It was found that out of the four categories two of them are behaviorist (communication and critical 
thinking), while the categories independent learning and collaborative work are constructivist, but, in the final average of the four categories the behaviorist approach prevails, as shown in Table 7. The hypothesis is rejected.

Table 7

Final Results

\begin{tabular}{|c|c|c|c|c|c|}
\hline \multicolumn{6}{|l|}{ Average } \\
\hline \multicolumn{2}{|c|}{ b-learning } & \multicolumn{2}{|c|}{ Face-to-face } & \multicolumn{2}{|c|}{ Online } \\
\hline Constructivist approach & Behaviorist approach & $\begin{array}{l}\text { Constructivist } \\
\text { approach }\end{array}$ & $\begin{array}{l}\text { Behaviorist } \\
\text { approach }\end{array}$ & $\begin{array}{l}\text { Constructivist } \\
\text { approach }\end{array}$ & $\begin{array}{l}\text { Behaviorist } \\
\text { approach }\end{array}$ \\
\hline 5.50 & 5.54 & 4.68 & 4.79 & 5.11 & 4.94 \\
\hline
\end{tabular}

\section{Conclusions}

A lot has been written on the topic of competencies, in theoretical terms of their advantages, disadvantages and the importance to relate them with a constructivist practice, but little has been done to measure in empirical terms of their development in face-to-face education and even less has it been tried to assess their performance in online and blended learning. The results of this research show that in general terms the development of competencies in the three modalities is basically behaviorist although particularly in online and b-learning modalities there are more constructivist aspects.

Communication category. The behaviorist approach prevails in the three modalities. Aspects such as the fact that students express that they make more abstracts than essays to express their ideas outstand. They share their doubts in the classroom and in the case of online learning in the time given by the professors. This is an evidence of the difficulty to be advised which may result in the lack of comprehension of a topic by the students. In the case of b-learning modality the students say that when they have to express an opinion they prefer to adapt the experts' or teacher's opinions than to express their own one.

Critical thinking category. Behaviorism prevails in the three modalities, particularly in text analysis, because the students do not know how to evaluate arguments and opinions expressed in the consulted information, even if they describe the main ideas of the topics. They are able to choose from different research methods and the information technologies which they use. That allows their search for information even though they do not know if the results are appropriate. In online learning, students consider they have been taught to describe main ideas from a text but they do not know how to build a hypothesis and how to prove its validity.

Independent learning category. The constructivist approach prevails in all three modalities, but the lowest average is found in the face-to-face modality. Students are able to look for information, though they only use the sources their teachers suggest. They are able to build their learning process and assume responsibility for it, leaving behind the belief that it is the teacher's responsibility. There is a high level of constructivism in the online and b-learning modalities as students are more mature and conscious that their learning is a responsibility of their own.

Collaborative work category. The constructivist approach prevails in the three modalities, even though the trend is weaker for face-to-face modality. When students participate in teamwork, they are more productive and can reach an agreement by accepting others' opinions. They say that their differences have advantages while participating in teamwork. Productivity outstood in online learning modality, because team work is richer than individual one. 


\section{References}

Alles, M. (2002). Management by competencies (Gestión por competencias). México: Ediciones Garnica.

Álvarez, I., Ayuste, A., Gros, B., Guerra, V., \& Romaña, T. (2003). Constructing knowledge with technology support for collaborative learning (Construir conocimiento con soporte tecnológico para un aprendizaje colaborativo). Revista Iberoamericana de Educación, 1(4), 1-15.

Andrade, J., \& Campo-Redondo, M. (2008). Information technologies (Tecnologías de información). Revista Mexicana de Investigación Educativa, 13(36), 223-248.

Argudín, Y. (2009). The education based on competences (La educación basada en competencias). México: Editorial Universidad Iberoamericana.

Barnet, R. (2001). The limits of competences. Knowledge, the higher education and society (Los límites de la competencia. El conocimiento, la educación superior y la sociedad). Barcelona: Editorial Gedisa.

Barrón, T. C. (2000). Education based on competences in the context of globalization processes. Competences training and professional certification (La educación basada en competencias en el marco de los procesos de globalización. Formación en competencias y certificación professional). México: Editorial CESU-UNAM.

Cabero, J. (1994). New technologies, communication and education (Nuevas tecnologías, comunicación y educación). Comunicación, colectivo para la educación en medios de comunicación Andalucía, España, 1(3), 14-25.

Cánchica, M., Chirinos, M., Cansen, M., Medina, N., \& Reyes, S. (2008). Approach to the dimensions of analysis of a mode of study from the basics of educational innovation with ICT (Aproximación a las dimensiones de análisis de una modalidad de estudio desde los fundamentos de la innovación educativa con TIC). Revista Cognición, 13(2), 1-8.

De Ibarrola, M. (2004). Recent paradox of education towards work and social inclusion (Paradoja reciente de la educación frente al trabajo y la inserción sociall). Buenos Aires: Editorial Redetis.

DeSeCo (Definition and Selection of Competencies). (2005). The definition and selection of key competencies. Executive Summary. OECD.

Del Toro, B. (2006). Distance education and ICT to support teaching and learning in health sciences (La educación a distancia y las TICs como apoyo para la enseñanza y el aprendizaje en ciencias de la salud). México: Editorial Universidad Autónoma de Guadalajara.

Díaz Barriga, A. (2006). The competence approach in education: An alternative or a costume change? (El enfoque de competencias en la educación: ¿una alternativa o un disfraz de cambio?). Perfiles Educativos, 28(111), 7-36.

Frade, L. (2007). Skills development in basic education, from preschool through high school (Desarrollo de competencias en educación básica: desde preescolar hasta secundaria). México: Editorial Calidad Educativa Consultores.

García, A. (2001). Distance education: from theory to practice (La educación a distancia: de la teoría a la práctica). Ecuador: Editorial Ariel.

González, J., \& Wagenaar, R. (2006). Tuning educational structures in Europe (La contribución de las universidades al proceso de Bolonia). Bilbao: Universidad de Duesto/Universidad de Groningen Press.

Ibarra, A. (1994). Problems and challenges of training in Mexico (Problemas y retos de la capacitación en México). Revista Mexicana del Trabajo, 6, 1-12.

INEE (Instituto Nacional de Evaluación Educativa). (2005). The quality of basic education in Mexico (La calidad de la educación básica en México). México.

Levinson, P. (1990). Computer conferencing in the context of the evolutions of media. L.M. Online Education. Perspectives on a new environment. New York: Praeger Press.

Levy-Leboyer, C. (2000). Management of the competencies (Gestión de las competencias). Barcelona: Ediciones Gestión.

Mansfield, J. B. (2004). Competence in transition. Journal or European Industrial Training, 28(4), 296-309.

Mertens, L. (1996). Labour competence: Emergence and models (Competencia laboral: sistemas, surgimiento y modelos). Montevideo: Cintefor/OIT.

Moreno, O. T. (2009). Competencies in Higher Education: a stop on the road to check the travel route (Competencias en Educación Superior: un alto en el camino para revisar la ruta de viaje). Perfiles Educativos, 31(124), 7-36.

Novick, M., Bartolomé, M., Miravalle, M., \& González, C. (1998). New jobs and labour competences (Nuevos puestos de trabajo y competencias laborales). Montevideo: Cinterfor/OIT.

Perrenoud, P. (2004). Ten new competencies to teach (Diez nuevas competencias para enseñar). Barcelona: Editorial Graó. 
Perrenoud, P. (2008). Building competencies do turn your back on knowledge? (Construir las competencias ¿Es darle la espalda a los saberes?). Revista de Docencia Universitaria, 2(6) 12-16.

Pérez, G. A. (2007). The nature of basic skills and teaching applications (La naturaleza de las competencias básicas y sus aplicaciones pedagógicas). Cuadernos de Educación de Cantabria, 1, 1-31.

Proyecto Tuning Latinoamérica. (2007). Final Report Tuning América Latina Project: Reflections and Prospects of Higher Education in Latin America 2004-2007 (Informe Final del Proyecto Tuning América Latina: Reflexiones y perspectivas de la Educación Superior en América Latina 2004-2007). Bilbao: Editorial Deusto.

SEP (Secretaría de Educación Pública). (2008). Comprehensive reform of upper secondary education (Reforma integral de la educación media superior). México: SEP.

Silva, M. (2008). Does it contribute Technological University to form the necessary competencies to professional performance (¿Contribuye la universidad tecnológica a formar las competencias necesarias para el desempeño profesional?). Revista Mexicana en Investigación Educativa, 13(38), 773-800.

Somovia, J. (1999). Decent job for all in a globalized economy (Un trabajo decente para todos en una economía globalizada). México: OIT.

Turpo, O. (2009). Development and perspective of blended learning mode of education in Iberoamerican University (Desarrollo y perspectiva de la modalidad educativa blended learning en la universidad de iberoamérica). Revista Iberoamericana de Educación, 50(6), 12-32.

Vila, N., Küster, I., \&Aldás, J. (2002). Development and validation of measurement scales in marketing (Desarrollo y validación de escalas de medida en marketing). Quadern de treball (p. 104) (Nova época). Facultad d’Economía, Universitat de Valencia.

Westera, W. (2001). Competences in education: A confusion of tongues. Journal of Curriculum Studies, 33(1), 75-88. 